\title{
Stratigraphy of the basalts of Savoia Halvø, central East Greenland
}

\section{Stuart Watt and Margrethe Watt}

In the early 1970 s the greater part of the basalts on the southern side of Scoresby Sund were mapped by the authors and a five-fold litho-stratigraphic division was established for the area as a whole. In 1971 C. H. Emeleus mapped the basalts on the eastern part of Savoia Halvø (Emeleus, 1971) and K. Birkenmajer examined the overlying Tertiary sediments (Birkenmajer, 1972). The main objective of the work in the summer of 1982 was to correlate the lava succession as mapped by Emeleus in 1971 with the stratigraphy established to the west and south-west. It was considered particularly important as the basalts here overlie black mudstones of Cretaceous age and also underlie the Eocene deposits of the Kap Dalton Formation. The authors have drawn extensively on Emeleus' mapping and have modified it according to the geological divisions used here.

The peninsula of Savoia Halvø lies at the northernmost end of the Blosseville Kyst which is affected by considerable coast-parallel faulting downthrowing to the south-east. The basis

Fig. 29. Selection of profiles through the Tertiary basalt lavas on Savoia Halvø.

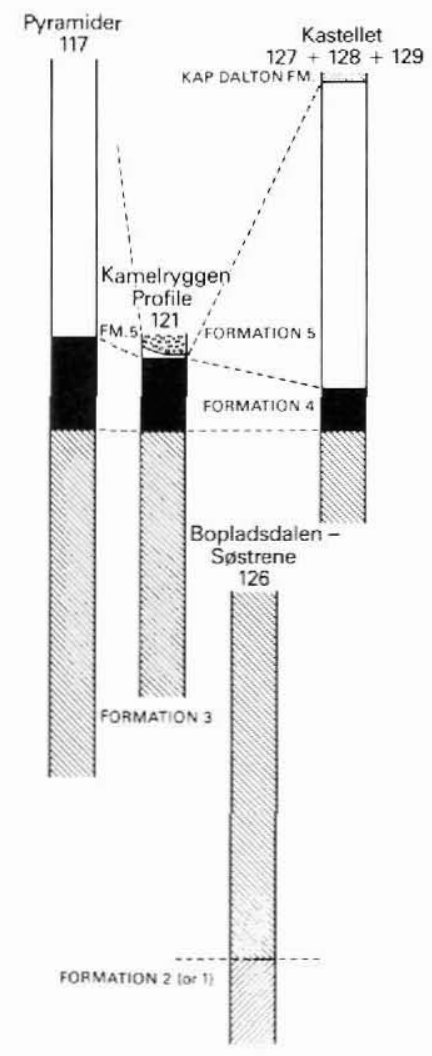




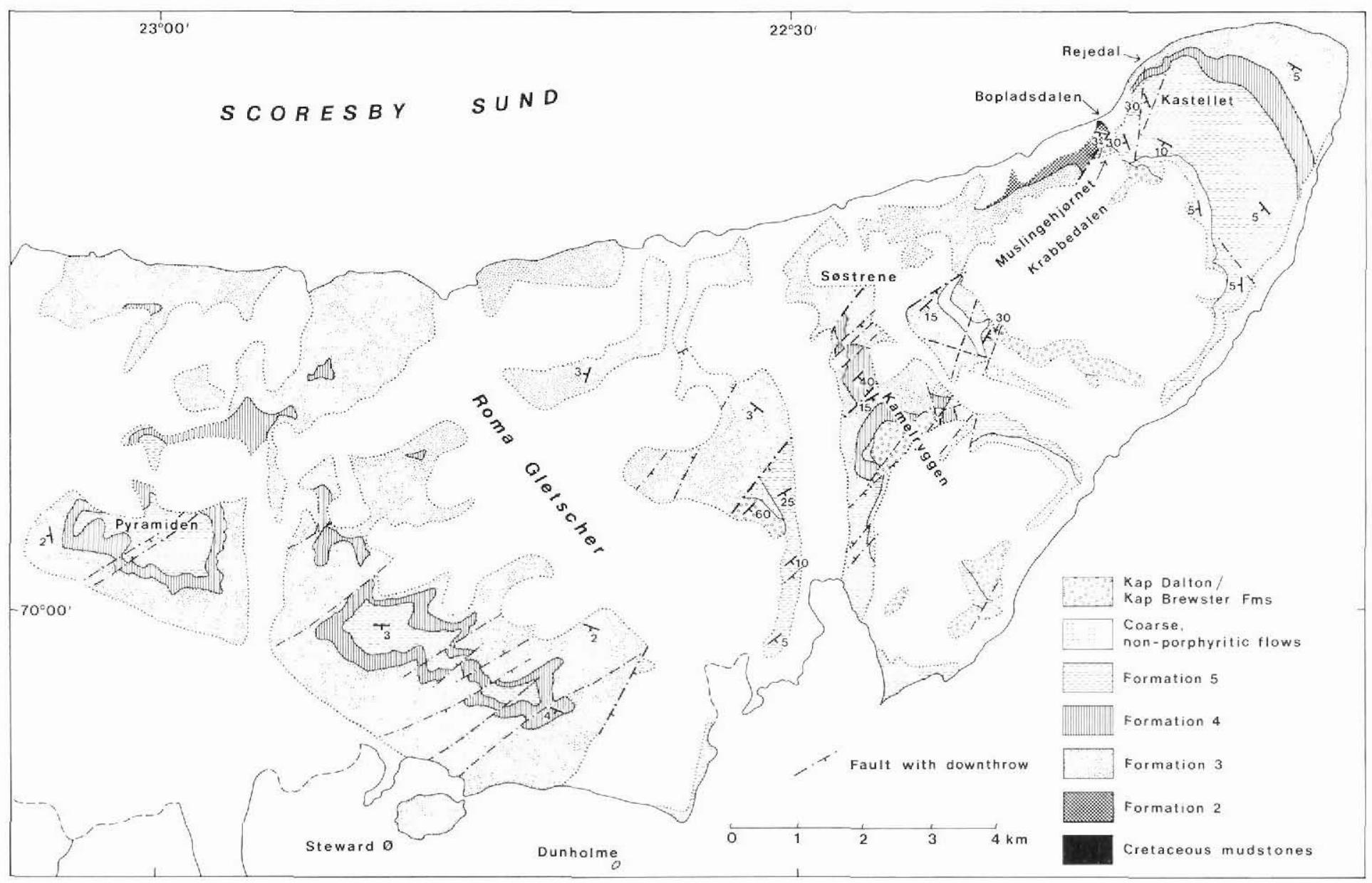

Fig. 30. Sketch map of Savoia Halvø showing the main faults and the general distribution of the Tertiary basalt lava formations. Map based on that of Emeleus (1971) with later amendments by the authors and certain details from Birkenmajer (1972). 
of the work was to build up as near complete profiles as possible through the exposed lava succession. The profiles range in length from about $1500 \mathrm{~m}$ at Pyramiden (1701 m) (Fig. 29) down to profiles of a few tens of metres scattered through the area. Care was taken to sample almost every flow, both in the major and the minor profiles. Due to poor exposure on the southern and eastern side of the peninsula some flows may have been overlooked.

To the west and south-west the basalt succession is divided into five formations which are in the process of being formally described. In this account they are numbered 1 to 5 from the bottom upwards.

Structurally the area falls in two parts; the north and west are relatively undisturbed with almost flat-lying lava flows forming steep, well-exposed mountains, while the southern and eastern part is block faulted and largely covered by drift. The division between these two areas coincides with the main zone of faulting parallel to the south-east coast.

\section{Unfaulted, flat-lying basalts}

Pyramiden is the highest mountain top in the region, reaching $1701 \mathrm{~m}$ in altitude. As it lies within the area of the flat-lying, essentially unfaulted lavas (fig. 30), the profile measured here is used as a standard profile in the area. Due to its length of $1500 \mathrm{~m}$ it is important as a means of linking up the broken sequences in the east.

The Pyramiden profile, from $200 \mathrm{~m}$ above sea level to the top, spans the greater part of three basalt formations. The lower part of the profile consists of $950 \mathrm{~m}$ of a monotonous sequence of thick (frequently $50 \mathrm{~m}$ ) flows of fine-grained, sparsely porphyritic basalt with occasional, small plagioclase phenocrysts of up to $5 \mathrm{~mm}$ size, frequently as clusters, interspersed with non-porphyritic flows. This sequence is assigned to the formation 3 established further west.

At $970 \mathrm{~m}$ there is a marked change in character of the flows. The lowest flow of the following sequence is characterised macropetrographically by being non-porphyritic at the base of the flow, but phenocrysts increase in number and size higher in the flow. The phenocrysts may show a planar arrangement, or form numerous stellate aggregates up to 60 $\mathrm{mm}$. Many of the flows are compound with no clear demarcation between individual units except occasionally where there are red, ropy lava surfaces. At about $100 \mathrm{~m}$ above the base of the sequence there are two thin pyroclastic layers which are probably of only local extent followed by a $10 \mathrm{~cm}$ thick sandstone horizon. The highest lavas (within this group) are without phenocrysts. The whole of this more heterogeneous sequence of $200 \mathrm{~m}$ of flows is referred to as formation 4 which is better developed to the south-west.

The character of the flows changes again at $1175 \mathrm{~m}$ where the profile continues with a thick, relatively homogeneous group of flows broken occasionally by thin flows of the same character as those in the underlying formation. The vast majority of flows within this sequence are porphyritic with fairly numerous or even dense, small plagioclase phenocrysts forming tight equidimensional aggregates of 2 to $8 \mathrm{~mm}$. The number and size of the aggregates are characteristic for this sequence of flows which normally also contain varying amounts of 1 to $2 \mathrm{~mm}$ sized pyroxene phenocrysts. This sequence is referred to the fifth formation, recognised to the west and south-west.

At the eastern end of the peninsula north-west of the fault the basalt flows have a slight westerly component of dip of up to $4^{\circ}$. This is sufficient to expose an underlying sequence of 
black mudstones (with partings $064 / 56^{\circ} \mathrm{S}$ ) of supposedly Upper Cretaceous age at the Bopladsdalen settlement (R. A. Fensome, personal communication, 1980). The overlying basalt sequence is equivalent to formation 2 recognized further west on Milne Land. This latter formation lies within the lower part of the total lava sequence and is further west underlain by a few hundred metres of basalt exposed only in the inner part of the Scoresby Sund fjord complex. The actual contact between the mudstone sequence and the lowest lava flows at Bopladsdalen at $75 \mathrm{~m}$ above sea level, is hidden by about $20 \mathrm{~m}$ of scree. The lowest flows exposed are massive and non-porphyritic divided by horizons of vesicular lava. They are followed upwards by a series of both porphyritic and non-porphyritic flows with scattered to numerous 10 to $30 \mathrm{~mm}$ plagioclase phenocrysts. Approximately $250 \mathrm{~m}$ above the top of the mudstones is a prominent yellow, arkosic sandstone 5 to $6 \mathrm{~m}$ thick.

\section{Area of block-faulted basalts}

South of the main NE-SW fault (fig. 30) the basalt flows are faulted into blocks with dips generally varying between $10^{\circ}$ and $30^{\circ} \mathrm{SE}$. Detailed correlation of these basalts is dependent on the recognition of a sequence of flows, and most blocks may reasonably easily be placed within a formation.

The basalts in the faulted area may be typified by the massive block of Kastellet at the eastern end of the peninsula. Here the basalt flows dip from about $5^{\circ}$ in the south up to $30^{\circ}$ close to the main fault.

The profile at Rejedal, on the northern side of this block, consists from sea level upwards of a few relatively thick, sparsely porphyritic flows (formation 3) overlain at $200 \mathrm{~m}$ by a series of thin flows typical of those of the formation 4 , but reaching only $100 \mathrm{~m}$ in thickness. Within this formation a sedimentary horizon of a coarse, dark grey, sandstone composed entirely of angular basaltic fragments occurs at $230 \mathrm{~m}$ above sea level. It is overlain by a local, thin, lignite horizon forming pockets of variable thickness, in places reaching $5 \mathrm{~m}$. The sequence of thin flows is followed by a sequence of larger flows with numerous 3 to $6 \mathrm{~mm}$ plagioclase aggregates similar to those of the formation 5. A thick pyroclastic layer forms a marked ledge at about $300 \mathrm{~m}$ where the contact is sufficiently well exposed. Sedimentary bands with silicified wood and baked shale is seen between most flows. These features agree well with observations made in the lower part of the formation 5 north-west of the main fault zone, indicating a more widespread terrestrial erosion and soil accumulation between eruptions than otherwise observed in the formation 5.

Due to the dip of the flows on the southern flank of Kastellet the stratigraphically higher flows occur on the poorly exposed south-western slopes. The uppermost of the lava flows here are coarser grained and without macroscopic phenocrysts. The exact thickness of this group of flows is uncertain due to repeated faulting. At least four flows of the coarse, non-porphyritic type lie directly above the flows of the formation 5. They also immediately underlie the sediments of the Kap Dalton Formation in Krabbedalen and frequently outcrop near sea level along the southern coast of the peninsula close to Kap Dalton Formation sediments. 


\section{Relationship of the Kap Dalton sediments to the basalts}

At Krabbedalen conglomerates at the base of the Kap Dalton Formation (Birkenmajer, 1972) rest directly on the coarse-grained, deeply weathered, non-porphyritic basalts which overlie the formation 5. On the western side of Kamelryggen a massive to stratified conglomerate, clast to matrix-supported, of $50 \mathrm{~m}$ thickness with lenses of pebbly sandstone consisting largely of well-rounded, basaltic pebbles directly overlies the deeply weathered lowest basalt flow of the formation 5 . The pebbles are mostly porphyritic, the majority with phenocryst density and forms like those of formation 5 with a few of the characteristic type of formation 4. The conglomerate on Kamelryggen is believed to be part of the Kap Dalton Formation.

\section{Main NE-SW fault zone}

The major fault which divides the peninsula from NE to SW is not everywhere a simple fault but is frequently made up of groups of faults often forming wedge-shaped blocks. At Muslingehjørnet where there is considerable displacement along a single fault plane a mylonite has developed. Here short sequences of the uppermost lavas overlain by sediments of the Miocene Kap Brewster Formation are brought down to the level of the flows of the formation 2. This implies a displacement in excess of $1500 \mathrm{~m}$, a figure essentially in agreement with that obtained by Emeleus (1971). On the southern side of the mountain of Søstrene $5 \mathrm{~km}$ to the west displacements are reduced to $600-700 \mathrm{~m}$.

To the west of Muslingehjørnet the fault line is marked by a clear scarp.

On the western side of Roma Gletscher a fault gully shows basalts of the formation 3 on the northern side juxtaposed with flows of the formation 5 on the south side. This fault is projected to run between Steward $\varnothing$ and the islands of Dunholme, the latter belonging to the formation 5 .

\section{Summary of the geological history of Savoia Halvø}

The volcanic activity in the area commenced with subaerial lava flows poured out over a surface of Late Cretaceous mudstones. These seem to have been tilted, and probably somewhat eroded before being covered by lava flows. The earliest flows in the Savoia Halvo area probably belong to the formation 2 which forms extensive tracts further west. A thick, but fairly local interbasaltic sandstone horizon of non-basaltic origin of up to 5-10 $\mathrm{m}$ occurring $150 \mathrm{~m}$ above the top of the Cretaceous sediments indicates that non-volcanic rocks were still available for erosion at the time. The overlying, approximately $1000 \mathrm{~m}$ of mostly very thick lava flows appear, from the lack of erosion material between flows, to have followed in fairly rapid succession. Notable variations over quite short distances in the thickness of individual flows indicate contemporaneous subsidence or minor faulting close to the later zone of major faulting.

The period of rapid extrusion was followed by a change in the character of the volcanic product together with an apparent decrease in the volcanic activity indicated by frequent interbasaltic soil horizons compared to the same stratigraphic levels to the south-west. Flows 
are more heterogeneous and pyroclastic and thin sandstone horizons with lignite products are more frequent. Sagging of the crust probably became appreciable at this time with local erosion.

The topmost four flows of the total succession are of a type not recognised with certainty elsewhere in the region, either because they never existed or because they were removed by subsequent erosion.

The magmatic activity was followed by rapid uplift and subsequent foundering of the coastal zone with the formation of large fault scarps. The faulting produced a marked shoreline with conditions for rapid erosion and the deposition of beach conglomerates which gradually gave way to coarse sandstone with a nearshore fauna and finally to marly siltstones with concretions of hard calcareous siltstone sometimes with crabs, and occasional basalt pebbles, forming the Kap Daiton Formation.

The Kap Brewster Formation represents a repeat of the process after renewed activity on the same fault line with large boulders at the base of the fault scarp and coarse sandstones, interpreted by Birkenmajer (1972) as a river-lag deposit further away from the fault scarp.

\section{References}

Birkenmajer, K. 1972: Report on investigations of Tertiary sediments at Kap Brewster, Scoresby Sund, East Greenland. Rapp. Grønlands geol. Unders. 48, 85-91.

Emeleus, C. H. 1971: Geology of Savoia Halvø between Kap Brewster and about 23 W. 44 pp. Unpubl. intern. GGU rep.

\section{Source rock sampling, stratigraphical and sedimentological studies in the Upper Palaeozoic of the Jameson Land basin, East Greenland}

\section{F. Surlyk}

A drilling programme was initiated in Jameson Land in 1982 with the objective of obtaining fresh cores of possible hydrocarbon source rocks. The area was chosen (1) because it exposes a thick, easily accessible and well studied Late Palaeozoic - Mesozoic sequence which is also supposed to extend eastwards to the off-shore shelf area of northern East Greenland; (2) because together with North Greenland it represents the only possible target for on-shore oil exploration in Greenland; and (3) because a petroleum concession to the area is at present being negotiated between ARCO/Nordisk Mineselskab and the authorities.

Thus there are very good short-term as well as long-term reasons to obtain a better knowledge of the nature and distribution of possible source rocks in the Jameson Land basin. The drilling programme was supplemented by studies of the Late Palaeozoic basin configuration and facies. In particular the Upper Permian basin was selected for detailed 